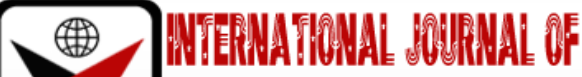

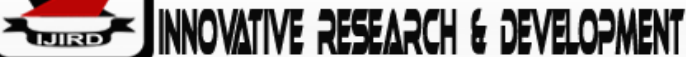

ISSN $2278-0211$ (Online)

\section{Evaluation of Branding as a Tool for Entrepreneurship Success}

J. Adeeko
Assistant Lecturer, Department of Entrepreneurship Education,
Bamidele Olomilua University of Science and Technology, Ikere-Ekiti, Nigeria
O. B. Oyekunle
Research Assistant, Centre for Entrepreneurship and Innovation,
University of Ibadan, Nigeria
O. Osunade
Associate Professor, Department of Computer Science,
University of Ibadan, Nigeria

\section{Abstract:}

This study evaluated branding as a tool for entrepreneurship success. The study is delimited to bakeries in IkejiArakeji Area in Ori-Ade Local Go vernment of Osun State, Nigeria. The study is guided by three research questions and seeks to know the effects of packaging, customer's taste and product's price on the growth of bakeries, rate of patronage, volume of sales and customer's choice. Five companies producing bread and two hundred bread customers are considered. A descriptive survey research design is used to determine the effects of branding on the success of entrepreneur among companies producing bread products. The data collected is analyzed using simple frequency counts, percentage mean and standard deviation. The results from the study revealed that unique packaging has ability to increase customer's patronage and that an increase in patronage results into an increase in sales which in turns impacts business growth. The results also revealed that customers buy more of bread from which they derive high satisfying taste. It is also shown in the results that quality of bread is not determined by price and that people tend to buy more of the bread that are carrying lower prices irrespective of their quality. Going by the results obtained, the study concluded that adequate and unique branding influence entrepreneurship success. The study therefore recommends that firms should endeavor to improve their branding system as this will enable them to remain relevant in market and stand the phase of competition.

Keywords: Packaging, entrepreneurship, taste, Nigeria

\section{Introduction}

The world is now in a communication dispensation and everyone is continually exposed to information. Competition rate has sprout up in the business world and many companies want to stand out amidst of competition and reach their customers via new and traditional media, computers and recently, even in our pockets through our mobile phones. Developing a successful brand system in the market world is a great challenge for new enterprises. A strong brand can lead to persistent competitive advantage on the market. Thus, the role of the brand is becoming increasingly important in order to differentiate themselves towards competitors (Isaksson, 2005).

It is widely known that new ventures lack internal structures; identity and resources and therefore they face many different challenges. One of the great challenges is to reach out to their audience by establishing a brand. It is known that establishing a successful brand enhances the possibilities for customer acquisition and retention to build favorable reputation. Marketing and especially branding can be seen as the interface between a small company and its external environment (Isaksson, 2005).

Entrepreneurs face a host of decisions in handling marketing tasks. These range from major decisions such as what product features to design into a new product, how many salespeople to hire, or how much to spend on advertising, to minor decisions such as the wording or color for new packaging. Among the questions that entrepreneurs ask (and will be addressed in this text) are: How can we spot and choose the right market segment(s)? How can we differentiate our products or services? How should we respond to customers who press for a lower price? How can we compete against lower-cost, lower-price rivals? How far can we go in customizing our offering for each customer? How can we grow our business? How can we build stronger brands? How can we reduce the cost of customer acquisition and keep customers loyal? How can we tell which customers are more important? How can we measure the payback from marketing communications? How can we improve sales-force productivity? How can we manage channel conflict? How can we get other departments to be more customers oriented? 
However, as the competitive turbulence become a constant in business environment, the goal itself is not to predict the future, which Drucker (1998) regarded as a lofty idea in the first place- but to anticipate a future made possible by the effect of changes taken place and made possible by the existing process as it intertwined with the present and stimulates the future. Within the framework of this study, the author examines brand management as a tool for success in entrepreneurship. The study begins with an appraisal of branding as a competition policy followed by explanation for key elements of branding as a marketing principle that serves as the basis for anticipation of future demand amidst 'permanent change'. It then highlights relevant guidelines that entrepreneurs could follow in formulating and implementing branding policy.

\subsection{Statement of the Problem}

It can be said categorically that "the marketplace isn't what it used to be." It is changing radically as a result of major forces such as technological advances, globalization and deregulation. These forces have created new behaviors and challenges; Customers increasingly expect higher quality and service and some customization, brand manufacturers are facing intense competition from domestic and foreign brands, which is resulting in rising promotion costs and shrinking profit margins, store-based retailers are suffering from an oversaturation of retailing.

Enterprises of today are aspiring to achieve increase customer's patronage and that an increase in patronage results into an increase in sales and in increase in sales impacts business growth. In our competitive market, everyone is struggling to improve and satisfy the needs of the customers. An enterprise cannot survive without constant patronage which will leads to sales growth. Previous works have established how branding has changed the perceptions of the customers about different products and the effects on their loyalty to the companies. Most enterprises of today are failing because there is low level of patronage and that is why branding has to be taken more seriously. Brand basically has to do with creating a new name, logo or symbol for a new product thereby increasing the level of patronage that leads to increase in sales of business (Keller, 2013).

Today, a number of enterprises are trying to get a high market share in order to survive a high market share in order to survive the ever-competitive market. Many of them believe that this can be achieved through effective branding. The challenge many firms have today is the cost of branding that will shrink their profits which have made a lot of firms to neglect branding (Tether 2013). Hence, this research looks at Evaluation of branding as a tool for the success of entrepreneur.

\subsection{Objectives of the Study}

The aim of this study is to investigate branding as a tool for success in entrepreneurship using companies producing breads in Ikeji-Arakeji in Ori-Ade LGA of Osun State, Nigeria and the following are the objectives that this research work tends to achieve:

- To assess the way packaging technique, adopt by the bread industries enhance the growth of bakeries.

- To ascertain the effect customer taste, have on the rate of patronage of bread among bakeries.

- To identify the role price plays in determining the volume of sales of bread.

\subsection{Research Questions}

- In what way can the packaging technique adopted by the bread industries enhance the growth of bakeries?

- What effect does customer taste have on the rate of patronage of bread among bakeries?

- In what way can the price determine volume of sales of bread?

\section{Literature Review}

Farhana (2014) defines a brand as a strategic asset; it could be seen as a promise that constantly needs to be delivered upon in order to gain brand equity. The substance of what a brand is, or for who it is, is found in the brand identity. Svedberg (2014) argues that the identity is the substance of what the brand is. It is through the identity that the venture can create its promises. The identity of a new venture is characterized by the culture, design, behavior and communication the venture has and it is the very essence of a brand. By establishing a successful brand Bresciani and Eppler (2010) argues that it enhances the possibilities for customer acquisition and customer retention, which in turn enhances the chances to build a favorable reputation. Brand equity is defined as a set of assets and liabilities, which is directly connected to the brand name and logo in order to add value to the customer (Aaker, 2004). Within this view as Keller (2003) says, technically speaking, whenever a marketer creates a new name, logo, or symbol for a new product, he or she has created a brand. He recognizes, however, that brands today are much more than that. As can be seen, according to these definitions, brands had a simple and clear function as identifiers.

Bresciani and Eppler (2010) argue that branding is crucial for establishing a new company. However, the entrepreneur often underestimates the company's ability to succeed and therefore fails to "think big". Branding is based on general considerations of the possible future of the business. Establishing a successful brand enhances the possibilities for customer acquisition and retention to build favorable reputation. However, many entrepreneurs have a lack of awareness about the importance of building a strong brand during their business creation process (Andersson, 2012). The reason for developing a strong brand is to highlight the uniqueness of an organization. Hence it is improving the possibilities of the company to succeed on the market (Rode and Vallaster, 2005). When branding a venture, the company stands in front of many challenges. New ventures lack an established identity, its reputation and internal structures are unformed and there is a lack of knowledge over what branding is and how important it is (Bresciani and Eppler, 2010; Rode and Vallaster, 2005). 
One challenge, according to Rode and Vallaster (2005) and Boyle (2003), is the lack of resources, the low knowhow and the little amount of time that can be spend on these types of issues. However, marketing and especially branding can be seen as the interface between a small company and its external environment. Hence, it can differentiate between surviving and failing start-up companies (Stokes, 2006). In the process of building a strong brand, both interactions with consumers (Gardner, 2014) and strategizing are important (Bresciani and Eppler, 2010), however, theories concern both are difficult to find. As companies focus extensively on their service offering and their customers on the market place of today, the theoretical framework causes problem on service logic and entrepreneurial marketing. Furthermore, two schools of brand building are outlined (Isaksson, 2005).

Chan (2004), in their study on "A Survey-Based Method for Measuring and Understanding Brand Equity and Its Extendibility" they develop a new survey-based method for measuring and understanding a brand's equity in a product category and evaluating the equity of the brand's extension into a different but related product category. It uses a customer-based definition of brand equity as the added value endowed by the brand to the product as perceived by a consumer. It measures brand equity as the difference between an individual consumer's overall brand preference and his or her brand preference on the basis of objectively measured product attribute levels. To understand the sources of brand equity, the approach divides brand equity into attribute-based and non-attribute-based components.

The study conducted by Arjun and Morris (2001), on the topic, "The Chain of Effects from Brand Trust and Brand Affect to Brand Performance: The Role of Brand Loyalty". The authors examine two aspects of brand loyalty, purchase loyalty and attitudinal loyalty, as linking variables in the chain of effects from brand trust and brand affect to brand performance (market share and relative price). The results indicate that when the product- and brand-level variables are controlled for, brand trust and brand affect combine to determine purchase loyalty by high market share and attitudinal loyalty by high relative price.

James et al. (2001), in their research paper titled, the Effect of Brand Attitude and Brand Image on Brand Equity operationalizes brand equity and empirically tests a conceptual model adapted from the work of Aaker (1991) and Keller (1993) considering the effect of brand attitude and brand image on brand equity. The results indicate that brand equity can be manipulated at the independent construct level by providing specific brand associations or signals to consumers and that these associations will result in images and attitudes that influence brand equity. The results suggest that focusing on the constructs that create brand equity is more relevant to managers than trying to measure it as an aggregated financial performance outcome.

The research findings of Peter et al. (2003), in their paper, A Comparison of Online and Offline Consumer Brand Loyalty, the authors' compared consumer brand loyalty in online and traditional shopping environments for over 100 brands in 19 grocery product categories. They compared the observed loyalty with a baseline model, a new segmented Dirichlet model, which has latent classes for brand choice and provides a very accurate model for purchase behavior. The results show that observed brand loyalty for high market share brands bought online is significantly greater than expected, with the reverse result for small share brands. In contrast, in the traditional shopping environment, the difference between observed and predicted brand loyalty is not related to brand share.

Also, Yi Zhang in 2015 reviewed extant studies about the impact of brand image on consumer from perspective of customer equity. It also presented the shortcomings of current research and pointed out the trends for future study. While Huakuai and Ying (2011) in their study on brand management problems in SMEs using Gävle Vandrarhem and Chailease International Finance Corporation-Shenzhen Branch as their case study. They use Funnel model and empirical studies to solve the brand management problems encountered in SMEs. He identified three main problems in SMEs which are a narrow interpretation of brand management, a lack of resources and time, and also observed that less attention is given to brand management.

The majority of the previous works have established how branding has changed the perceptions of the consumers about different products and the effects of this on their loyalty to the companies. Some have tried to measure brand equity while some have revealed the customers satisfaction through brand management. However, no effort has been made to establish how branding can help entrepreneur achieve success and help the sustaining entrepreneurial activities in the business organization. This study tends to bridge the gap by trying to establish the effect of branding on every entrepreneurial activity in companies producing similar products and also offers suggestion on the area that needs to be covered in future research.

\section{Methodology}

In the study, a descriptive survey research design was used to determine the effects of branding as a tool for the success of entrepreneur among companies producing similar products using companies producing bread in Ikeji-Arakeji, Ori-Ade LGA of Osun State, Nigeria as a case study. A sample size of 200 bread consumers and 5 managers of the bakeries in Ikeji-Arakeji were selected using simple random sampling techniques and total enumeration technique respectively. The simple random sampling method gives members of the population (customers) equal chance of being selected to partake in the study without any element of influencing the chance of selecting the others, while total enumeration was used to include the bakery managers of all the bread producing firms in Ikeji-Arakeji, Ori-Ade LGA, Osun State, Nigeria. Primary data was collected using sets of well-structured questionnaires for the managers and the customers. These questionnaires were constructed to enable the respondents indicate their opinions about the problem of the study; this was supported by personal interview where necessary to have face to face interaction with the respondents. The questionnaires were constructed to have two parts of five sections. Part one captured the demographic information of the respondents while part two was constructed to give answers to the research questions. 


\section{Results and Discussion}

\subsection{Demographic Characteristics of the Respondents}

This section analyses the socio-economic characteristics of the bakery managers and those of their customers' respectively. The responses of managers of the five (5) selected bakeries were analyzed and tabulated in Table 1

\begin{tabular}{|c|c|c|}
\hline Variable & Frequency & Percentage (\%) \\
\hline Gender & 5 & 100 \\
Male & 5 & 100 \\
Total & 1 & \\
\hline Marital Status & 4 & 20.0 \\
Single & 5 & 80.0 \\
Married & 3 & 100 \\
Total & 2 & 60.0 \\
\hline Age Range & 5 & 40.0 \\
31-45 & & 100 \\
46-60 & 2 & 40.0 \\
Total & 1 & 20.0 \\
Educational Level & 1 & 20.0 \\
SSCE & 1 & 20.0 \\
Diploma/NCE & 5 & 100 \\
B.Sc or its equivalent & & \\
Post Graduate & 1 & 20.0 \\
Total & 1 & 20.0 \\
\hline Company's name & 1 & 20.0 \\
Bakery 'A' & 1 & 20.0 \\
Bakery 'B' & 1 & 20.0 \\
Bakery 'C' & 5 & 100 \\
Bakery' 'D' & 5 & \\
Bakery 'E' & 5 & \\
Total & & \\
\hline
\end{tabular}

Table 1: Socio-Economic Characteristics of the Respondents

\begin{tabular}{|c|c|c|}
\hline Variables & Disagree & Agree \\
\hline Well packaged products help in attracting more sales & - & $5(100 \%)$ \\
\hline Packaging is a way of adding value to product/services. & - & $5(100 \%)$ \\
\hline Good packaging enhances customer retention. & - & $5(100 \%)$ \\
\hline The organisation image can be promoted through branding & - & $5(100 \%)$ \\
\hline Packaging is a good way of differentiating products from competitors. & - & $5(100 \%)$ \\
\hline Packaging is a mean of increasing company's output. & - & $5(100 \%)$ \\
\hline Effective packaging promotes patronage & - & $5(100 \%)$ \\
\hline
\end{tabular}

Table 2: Ways by which Packaging Techniques Adopt by the Bread Industries

Enhance the Growth of Bakeries (Managers Opinion).

\subsubsection{Analysis of Research Question 1} Arakeji?

In what way can the packaging techniques adopt by the bread industries enhance the growth of bakeries in Ikeji-

The results in the Table 2 reveal that all the managers $5(100 \%)$ agreed that well packaged products help in attracting more sales, all of them $5(100 \%)$ agreed that Packaging is a way of adding value to product/services. The results also show that all of the bakery managers $(100 \%)$ agreed that good packaging does not only enhance customer retention, but also promotes organization image in the market. The results also show that all the managers $(100 \%)$ agreed to packaging as a good way of differentiating products from competitors, all of them also agreed that packaging is a mean of increasing company's output and $100 \%$ of the managers agreed that effective packaging promotes patronage. This implies that all the managers are aware of the importance of packaging to the growth of their businesses. 


\begin{tabular}{|c|c|c|}
\hline Variables & Disagree & Agree \\
\hline We often eat bread 1-2 times a week & $3(1.5 \%)$ & $196(98.5 \%)$ \\
\hline We eat bread everyday & $10(5.0 \%)$ & $190(95 \%)$ \\
\hline When my favourite bread is not available, I buy others & $25(12.5 \%)$ & $175(87.5 \%)$ \\
\hline I can taste differences among breads & $2(1 \%)$ & $198(99 \%)$ \\
\hline My Preferred bread is called & Frequency & Percentage (\%) \\
Bakery A & 98 & 49 \\
Bakery B & 27 & 13.5 \\
Bakery C & 25 & 12.5 \\
Bakery D & 28 & 14.0 \\
Bakery E & 22 & 11.0 \\
Total & 200 & 100.0 \\
\hline Bakery A & Frequency & Percentage (\%) \\
Bakery B & 98 & 49 \\
Bakery C & 27 & 13.5 \\
Bakery D & 25 & 12.5 \\
Bakery E & 28 & 14.0 \\
Total & 22 & 11.0 \\
\hline Which bread has the best taste & 200 & 100.0 \\
\hline
\end{tabular}

Table 3: Effect of Customer Taste on the Rate of Patronage of Bread among Bakeries (Customers Opinion)

\subsubsection{Analysis of Research Question 2}

What effect does customer taste have on the rate of patronage of bread among bakeries in Ikeji-Arakeji?

Meanwhile, the analysis of customers' opinions on the effects of taste on the rate of bread patronage as tabulated in Table 3b reveals that majority of the customers 196 (98.5\%) agreed that they often eat bread 1-2 times in a week. Meanwhile, 190 (95\%) of them still said they often eat bread every day. These results show an inconsistency in the opinions of the customers as to the rate at which they consume bread. Majority of the customers 175 (87.5\%) agreed that they usually buy another bread product whenever their favourite bread brand is not available. Almost all the customers 198 (99\%) agreed that they could taste differences among the bread produced in Ikeji-Arakeji. When almost half $98(49 \%)$ of the customers preferred Bakery A and identified it as the bread with the best taste, 27 (13.5\%) love to eat Bakery B bread, 25 (12.5\%) love to eat Bakery Cbread, 28 (14\%) preferred buying Bakery D bread and 22 (11\%) of the customers like buying Bakery El bread and same percentage identified it as the bread with the best taste. The result implies that among all the bread makers in Ikeji-Arakeji, Bakery A, bread is the most preferred and the bread with the best taste and so are ready to pay more prize in obtaining it

\begin{tabular}{|c|c|c|}
\hline Variables & Disagree & Agree \\
\hline My bread choice is determined by the price in market & $2(1.0 \%)$ & $198(99.0 \%)$ \\
\hline The quality of a bread justifies its price & $1(0.5 \%)$ & $199(99.5 \%)$ \\
\hline Consumers buy more of a bread based on their prices & $1(0.5 \%)$ & $199(99.5 \%)$ \\
\hline $\begin{array}{l}\text { I would be willing to pay somewhat higher prices in order to appreciate } \\
\text { the benefits provided by the product }\end{array}$ & $19(9.5 \%)$ & $181(90.5 \%)$ \\
\hline I buy bread that does not lose taste easily & - & $200(100 \%)$ \\
\hline $\begin{array}{l}\text { The price put on my best bread commensurate with the satisfaction I } \\
\text { derived from it. }\end{array}$ & $1(0.5 \%)$ & $199(99.5 \%)$ \\
\hline Bread products with higher prices give higher satisfaction & $17(8.5 \%)$ & $183(91.5 \%)$ \\
\hline $\begin{array}{l}\text { Bread products with lower prices attract more patronage irrespective of } \\
\text { their qualities. }\end{array}$ & 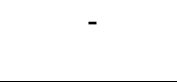 & $200(100 \%)$ \\
\hline
\end{tabular}

Table 4: Price as a Branding Tool among Bread Makers/Producers in Ikeji-Arakeji (Customers' Opinion)

\subsubsection{Analysis of Research Question 3}

In what way can the price determine volume of sales of bread in Ikeji-Arakeji?

Table 4 shows that customers opinion on the effects of price on the sales and performance. The table reveals that almost all the customers 198 (99\%) agreed that they buy bread based on their prices in the market. 199 (99.5\%) of the respondents agreed that the quality of a bread justifies its price and consumers buy bread based on the price in the market. This is in relation with what the manager said about price of their products. The implication of this is that bread products are sold based on the quality of the bread; that high quality bread products are sold with high prices while low quality bread products are cheaper in the market. The results also revealed that all the customers $200(100 \%)$ buy bread that does not lose taste easily. Almost all the customers 199 (99.5\%) admitted that the prices put on their bread choice commensurate with the satisfaction they derived from the products. Moreover, 183 (91.5\%) of the respondents agreed that bread products with higher prices give higher satisfaction. However, all the customers $200(100 \%)$ agreed that bread products with lower prices attract more patronage irrespective of their qualities. 


\section{Conclusion}

Going by the results obtained, product branding can be in form of packaging, taste and price. Depends on their adoptions, all of these are special tools, if well managed, can influences entrepreneurship success of bread producers. Each element of branding plays a different and unique role in production, level of sales and customers' satisfaction. It is discovered in the study that the customers' taste, their purchasing power and level of satisfaction derived from the bread products influences their decision to buy and consequently, impacts on company sales, level of output and the success of the firm. Since packaging, taste, price and size of products enhance an increase in customer's patronage and consequently influence growth of the organization, products firms should therefore endeavor to improve their branding system, and this will enable them to remain relevant in market and in the face of competition. Therefore, bread makers should strategies a way of better integration of these elements in their productions process.

\section{References}

i. Aaker, David A 2004.Brand Portfolio Strategy. Creating Relevance, Differentiation, Energy, Leverage and Clarity. New York, Free Press. ----- (2004b), "Leveraging the Corporate Brand" California Management Review, 46 (3), 6 18.

ii. Arjun and Morris (2001), "The Chain of Effects from Brand Trust and Brand Affect to Brand Performance: The Role of Brand Loyalty. Journal of Marketing 72-85

iii. Andersson M. 2012. The Function and Characteristics of Cluster Branding. International Place Branding Conference 41-49

iv. Bresciani, S. \&Eppler, M.J. 2010 'Brand new ventures? Insights on Start-ups Branding Practices'. Journal of Product \& Brand Management, Vol.19 No.5, pp. 356- 366.

v. Boyle, E. 2003A study of Entrepreneurial Brand Building in the Manufacturing Sector in the UK. Journal of Product \& Brand Management, Vol.7 No.2, pp. 79-93.

vi. Chen G. 2018. Nine ways to Creatively Launch A Personal Brands. Forbes Hatch, M. J. and Majken S.2003.Bringing the Corporation into Corporate Branding, European Journal of Marketing, 37 (7/8), 1041-1064 Hatch, M. J. and Majken S.2003.Bringing the Corporation into Corporate Branding, European Journal of Marketing, 37 (7/8), 1041-1064.

vii. Farhana M. 2014. Implication of Branding Identity Facet on Marketing, Communication of Lifestyle Magazine: case study of A Swedish Brand. Journal of applied Economics and Business Research 4(1)

viii. Hausman, A. 2000, A multi-method investigation of consumer motivations in impulse buying behaviour, Journal of Consumer Marketing, Vol. 17 No. 5, pp. 403-19.

ix. Huakuai H. and Ying L. 2011.The brand management problems in SMEs---Case study on GävleVandrarhem AB and Chailease International Finance Corporation-Shenzhen Branch

x. Isaksson F. 2015. Brand Building in New Ventures. University Gothenburg, School of Business and Law 25-43

xi. Keller, K. 1993 Conceptualizing, measuring, and managing customer-based brand equit', Journal of Marketing, 57: 1-22.

xii. Keller, K. L.2013, Conceptualizing, Measuring, and Managing Customer-Based Brand Equity, Journal of Marketing, 57 (January), 1-22. (2003a), Strategic Brand Management: Building, Measuring, and Managing Brand Equity, Upper Saddle River, Prentice Hall.

xiii. Logman, Marc 2004.The LOGMAN Model: A Logical Brand Management Model, Journal of Product and Brand Management, 13 (2), 94-104.

xiv. Rode V. and Vallster 2005. Corporate Branding for Start-ups. The Crucial Role of Entrepreneurias. Corporate Reputation Review, vol.8(2), 121-135

xv. Stokes D. 2000.Putting entrepreneurship into marketing: The process of entrepreneurial marketing. Journal of Research in Marketing \& Entrepreneurship, 2(1), pp. 1-16.

xvi. Stokes, D. 2006. Marketing and the small business. In Carter, S. \& Jones-Evans, D. (eds). Enterprise and Small Business: Principles, Practise and Policy. 2nd ed. London: Prentice Hall, pp. 324-337.

xvii. Svedberg, J. 2014. 'Nio resonemang om varumärken och varumärkeskommunikation', Göteborgstryckeriet, Nine Yards AB

xviii. Tether, B. 2013 Services, Innovation and Managing Service Innovation, in The Oxford Handbook of Innovation Managment, edsDodgeson, Gann and Philips, Oxford

xix. Yi Z., 2015.The Impact of Brand Image on Consumer Behavior: Department of Marketing, Management School, Jinan University, China. A Literature Review, vol. 3(1) 